\title{
WOMEN AND CREDIT IN PERU DURING THE GUANO ERA. WAS THERE GENDER DISCRIMINATION IN THE MORTGAGE CREDIT MARKET OF PERU?*
}

LUIS FELIPE ZEGARRA

CENTRUM Católica Graduate Business School ${ }^{\mathrm{a}}$

\begin{abstract}
This article analyses the role of women and gender discrimination in the mortgage credit market in Peru between 1860 and 1875. Relying on a large sample of notarised loans, the article shows that women participated in the credit market as lenders and borrowers. However, their participation was lower than that of men. In addition, women received smaller loans and paid higher interest rates than men. The evidence suggests that the lower participation of women as borrowers and their smaller loans were largely a consequence of the distribution of collateral. In addition, much of the difference in interest rates resulted from the differences in loan sizes. As women received smaller loans and there were probably fixed costs involved in granting a loan, making a loan to a woman implied a higher average cost.
\end{abstract}

Keywords: mortgage credit, economics of gender, property rights, Peru

JEL Classification: N26, N46, J16, K11

\footnotetext{
* Received 2 July 2013. Accepted 10 January 2014. The author thanks the assistance of the staff of the National Archives of Peru in the process of data collection, as well as the comments of the three anonymous referees.

a Jr. Daniel Alomía Robles 125-129, Los Alamos de Monterrico, Santiago de Surco, Lima 33, Peru. lfzegarrab@pucp.edu.pe
} 


\section{RESUMEN}

Este artículo analiza el papel de las mujeres y la discriminación por género en el mercado de crédito hipotecario en Perú entre 1860 y 1875 . Basándonos en una muestra significativa de préstamos notariales, el artículo muestra que las mujeres participaron en el mercado de crédito como prestamistas y prestatarias. Sin embargo, su participación fue menor que la de los hombres. Adicionalmente, las mujeres recibieron préstamos más pequeños y con mayores tasas de interés que los hombres. La evidencia sugiere que la menor participación de las mujeres como prestatarias y el menor tamaño de sus préstamos se debieron en gran medida a la distribución de colateral. Además, en gran medida las diferencias en tasas de interés se explican por las diferencias en tamaños de los préstamos. En la medida en que las mujeres recibieron préstamos más pequeños y hubo probablemente costos fijos en garantizar un préstamo, prestar dinero a una mujer implicó un mayor costo promedio.

Palabras clave: crédito hipotecario, género, derechos de propiedad, Perú

\section{INTRODUCTION}

Several studies have examined the importance of gender discrimination in credit markets ${ }^{1}$. Relying on data for the second half of the $20^{\text {th }}$ century, most of these studies do not find strong evidence to support the existence of gender discrimination. In particular, they show that gender does not influence the probability of approval of loan applications and interest rates in developed and developing economies, once relevant market factors and individual borrower characteristics are taken into account ${ }^{2}$.

The fact that there was no discrimination in the $20^{\text {th }}$ century, however, does not imply that there was no discrimination in early credit markets. Prejudice against women was probably stronger in the past, and, considering that early credit markets were largely informal and relied on personal linkages, prejudice may have had a large impact on credit allocation (Burnette 2008, p. 283). If prejudice against women influenced the perception of risk, then relative to men, women may have faced a higher probability of loan

1 The literature on gender discrimination in credit markets is far smaller than the literature on gender discrimination in labour markets (Morrison et al. 2007).

2 For evidence on gender discrimination in developed economies, see Asiedu et al. (2012), Avery et al. (1996), Blanchard et al. (2008), Blanchflower et al. (2003), Cavaluzzo and Cavaluzzo (1998), Schafer and Ladd (1980) and Edelstein (1977). For developing economies, see Storey (2004) for Trinidad and Tobago, Raturi and Swamy (1999) for Zimbabwe, Buvinic and Berger (1990) for Peru and Baydas et al. (1994) for Ecuador. In-depth reviews of the literature were carried out by Dymski (2006) and Yinger (1996). 
denial, or — if their loans were approved - women may have been charged higher interest rates and granted smaller loans, relative to their collateral.

Few studies have focused on the role of women in early credit markets ${ }^{3}$. Some studies notice that women had an active participation in credit markets. Shepard (2000), for example, mentions that women participated in credit markets (and in other economic activities) in England in the $16^{\text {th }}$ and $17^{\text {th }}$ centuries (Shepard 2000, pp. 166-167). Other studies show that female lenders were important sources of credit in Michigan in the $19^{\text {th }}$ century and Paris in the $18^{\text {th }}$ and $19^{\text {th }}$ centuries ${ }^{4}$. The fact that women participated in the early credit markets as lenders and borrowers, however, does not necessarily imply that there was no gender discrimination. In fact, Pressnall (1956) argues that during the Industrial Revolution, the "very personal nature of private banking» may have resulted in discrimination against women (Pressnall 1956, p. 296). Burnette (2008), however, argues that gender discrimination in the Industrial Revolution operated through the family, not through the credit market. In spite of these studies, our knowledge of the role of women in credit markets and, especially, gender discrimination is still very limited.

This article explores the role of women in the credit market and the possible existence of gender discrimination in a small Latin American economy in the $19^{\text {th }}$ century. In particular, the article looks at the Peruvian case during the guano era. By relying on a large sample of notarised loans between 1860 and 1875, the article provides some explanations for the differences in participation in the credit market between women and men, and for the differences in interest rates and loan sizes.

Women participated in the Peruvian credit market during the guano era. Considering a sample of $>1,500$ loans by private lenders for 1860-1875, women lenders made around one-fourth of the total number of loans in the provinces of Lima and Callao, and women borrowers received around one-third of the total number of loans. Although women played an important role in credit markets, the access of women to credit was much lower than that of men. In addition, female borrowers did not face the same loan conditions as men. Women paid an average interest rate of 16.5 per cent per year, whereas men paid an average annual interest rate of 14.9 per cent. In addition, women received loans in smaller amounts than men. Loan sizes to women averaged 2,436 soles, whereas loan sizes to men were on average 3,926 soles.

3 The literature on financial history has paid limited attention to the role of women in early credit markets. Most historical studies on gender for the United States have focused on the role of women in the economy, portraying them as having unequal access to economic opportunities, but not on their role in credit markets (Heller and Houdek 2004).

4 See Heller and Houdek (2004) for Michigan and Hoffman et al. (1992) for Paris. Similarly, Levy (2012) shows that women participated actively in Yucatan' credit market throughout the $19^{\text {th }}$ century, although female borrowers paid higher interest rates than men. 
Why did women have less access to credit than men? Why did women pay higher interest rates and receive smaller loans than men? Is there evidence of gender discrimination?

From an economic point of view, there is gender discrimination in credit markets when differences in access to credit and loan conditions between women and men are based on prejudice ${ }^{5}$. Not all differences in access to credit and loan conditions between women and men, then, are caused by gender discrimination: there might be differences in relevant borrowers' individual characteristics between both genders. For instance, if women have weaker property rights over their assets, are less able to manage their finances and have less valuable collateral, lenders will probably not be willing to grant many loans to women, and many of the approved loans will be relatively small and at high interest rates ${ }^{6}$. There will be discrimination if lenders have a prejudice about the ability to women to repay their loans, and if they allocate loans influenced by such prejudice.

The article shows that differences in the participation in the credit market may be explained by differences in proprietorship and access to business opportunities, not necessarily by prejudice. In addition, much of the difference in interest rates was a result of differences in loan sizes. Women were charged higher interest rates than men to a large extent because the former received smaller loans than the latter and because there were probably fixed costs involved in granting a loan; not because of gender discrimination. Therefore, in spite of the prejudice against women, the evidence suggests that women and men were on the same credit rationing curve ${ }^{7}$.

The article constitutes an important contribution to the literature on financial history for three main reasons. First, there are only a few studies on the impact of gender on early credit markets, especially for Latin America ${ }^{8}$.

5 Becker (1957) conceptualised discrimination as personal prejudice. As Blanchflower et al. (2003) indicate, "discrimination occurs whenever the terms of a transaction are affected by personal characteristics of the participants that are not relevant for the transaction» (p. 930).

6 Asiedu et al. (2012), for example, consider that loan denial rates and interest rates may be affected by the applicant's characteristics (credit history and financial wealth), the firm's attributes (credit rating, net worth, organisation type and industry), characteristics of the loan and the lender (the type and the amount of the loan, type of lender and the length of the relationship with the lender), and the region and year of application.

7 Mortgage credit markets are usually described as rationing. Credit rationing exists when, in equilibrium, the demand for funds exceeds the supply of funds, a result in credit markets with imperfect information (Stiglitz and Weiss 1981).

8 The only study of the role of women in early credit markets in Latin America is the study of Mexico by Levy (2012). In the case of Peru, the role of women in the $18^{\text {th }}$ and $19^{\text {th }}$ centuries has been the main focus of a large number of studies. Hünefeld (1988), for example, analysed the role of female slaves in Lima between 1800 and 1854; Premo (2006) and Lévano (2006) discussed the education of women in late colonial Lima; whereas Cosamalón (1996) analysed the participation of women in the labour market of Lima in the $19^{\text {th }}$ century. However, these studies do not refer to the participation of women in early credit markets. 
Second, the article focuses on the guano era, an important period for Latin American historiography: the guano era was one of the fastest and most sustained periods of economic growth in Latin America. The literature has paid much attention to a variety of aspects of this period, but these do not include the role of women and the existence of gender discrimination ${ }^{9}$. Third, the article relies on notarial records. Notarial records have proved to be extremely useful for studying early credit markets in other countries ${ }^{10}$. However, although notarial records are available for $19^{\text {th }}$-century Peru, credit markets during the guano boom and certainly the role of women and property rights have not received much attention from the literature.

Importantly, our results are relevant for understanding credit markets and gender discrimination in a period of abundance of financial funds, such as the guano era ${ }^{11}$. Several studies conclude that in the presence of competition discrimination plays a minor role ${ }^{12}$. The abundance of financial funds may have increased competition, which may then have reduced the importance of gender discrimination ${ }^{13}$.

9 Several studies deal with the export sector, commercial banks and inflation (Camprubí 1957; Bonilla 1974; Hunt 1973; Gootenberg 1990). Peruvian credit markets have also received much attention from the literature. For colonial times, Suárez (2001) examines the evolution of credit markets. The PhD dissertation on coastal agriculture by Engelsen (1978) is the only study that has relied on primary data to study long-term credit in Peru during the guano era. However, Engelsen relies on loan data from only one notary, only examines agricultural credit (a small portion of all mortgage credit conducted by private lenders), and does not conduct a systematic analysis of the differences in loan conditions between private lenders and mortgage banks to determine whether the creation of these banks represented a significant change from the previous situation. Recently, Zegarra (2013a, 2013b) relied on a sample of notarised loans to study the impact of political stability and mortgage banks on the allocation of credit. Alfonso Quiroz was also a prominent historian who devoted much time to studying the evolution of credit markets in Peru: Quiroz (1994) analysed the role of credit in late colonial Peru, whereas Quiroz (1993) discussed the evolution of credit markets in Peru and its relationship with agricultural development in the late $19^{\text {th }}$ and early $20^{\text {th }}$ centuries.

${ }^{10}$ In recent decades, they have been used for studying credit markets in Paris from 1690 to 1840 (Hoffman et al. 1992), in Ontario, Canada, from 1795 to 1849 (Redish 2003), in Keene, New Hampshire between 1832 and 1915 (Beveridge 1985) and for analysing the effects of the Glorious Revolution on Great Britain's credit markets (Quinn 2001). For Latin America, Levy (2012) recently relied on notarial records for analysing the evolution of credit markets in $19^{\text {th }}$-century Yucatan.

11 During this period of rapid economic growth, funds flew into the Peruvian economy and short- and long-term credit increased substantially. The first commercial banks started to operate in 1862 and by 1872 there were eleven commercial banks operating in the entire country. From 1866 mortgage banks also appeared in the market, offering long-term loans secured by real estate. As Quiroz (1993) indicates, "the sudden inflow of foreign capital triggered a temporary banking boom between 1869 and 1872». Quiroz (1993. As funds were abundant, the supply of credit was also much greater than in the 1820s and 1830s (Zegarra 2013a).

12 Becker (1957) argues that in the absence of competition it is possible to sustain noneconomic discrimination, and that competition reduces discrimination. Several empirical studies support this view. Levine et al. (2008), for example, find that deregulation, and thus more competition in financial markets, reduces racial discrimination. Cavaluzzo et al. (2002) also find that competition reduces discrimination.

${ }^{13}$ It is possible, then, that the scarcity of funds in the 1820 s and 1830 s reduced competition and increased the effect of prejudice on the allocation of credit. 
The structure of the article is as follows. Section 1 analyses the role of women in the Peruvian economy in the $19^{\text {th }}$ century. Section 2 discusses the differences in formal property rights between men and women. Section 3 describes some key facts about the Peruvian credit market in the 1860s and 1870s. Sections 4 analyses whether gender discrimination influenced the differences in the participation of women in the credit market and the differences in loan sizes between women and men. Section 5 determines whether gender discrimination led to differences in interest rates. Section 6 concludes the article. In addition, Appendix A.1 describes the sample of loans and the variables included in the econometric models.

\section{WOMEN IN THE PERUVIAN ECONOMY}

In $19^{\text {th }}$-century Peru, there was a widely held conception that women did not have the same role in the economy as men. In fact, several did not consider women as having the same needs or goals as men. For instance, it was a general belief that the main goal in life for women should be to get married. As Oliart (1995) indicates, the task of finding a husband appears as the central objective in the life of every woman in several $19^{\text {th }}$-century writings and paintings ${ }^{14}$. If a woman could not find a husband, she had one option left: she could become a beata (a lay religious woman). Getting married or, alternatively, becoming a beata were the two valid options according to $19^{\text {th }}$-century tradition and a woman with goals different from getting married or becoming a beata was usually strongly criticised.

The view that the main role of women was to be a good wife and mother may have been dominant. By 1847 the legislator Juan Celestino Cavero argued that the goal of female education was the formation of "tender mothers, faithful and resigned wives, docile and respectful daughters», because receiving the first inspirations of virtue from early life, it was convenient to educate "daughters in advance so that with the endearing love flame they print the stamp of virtues on the foreheads of their children» (Salinas 2011, p. 82). Religious and moral formation, then, constituted important elements of the education of girls from early life in order to contribute to their roles as mothers and wives. Similarly, according to the reputed Francisco García-Calderón (1879), the «nature» of women did not make them a good fit for the same positions as men (García-Calderón 1879, vol. II, pp. 1395-1396).

In spite of this prejudice against women, on average, women had a similar level of access to men to basic education. Schooling was always

14 The Peruvian writer Ricardo Palma, for example, described the mujeres casaderas (women who wanted to get married) as women who combined seducing skills and religious arguments when it was convenient to them, charming their wooers until the former ensured they were the right choice (Oliart 1995, p. 279). 
available to girls as well as boys ${ }^{15}$. Moreover, according to the Census of 1876, literacy levels in the province of Lima were very similar for men and women. Around 5 per cent of men and 8 per cent of women did not know how to read, 50 per cent of men and 46 per cent of women did not know how to write, and 45 per cent of men and 46 per cent of women did know how to read and write.

However, there were differences in the type of education and in access to higher education. As Zegarra (1998) indicates, before 1845 the subjects taken by girls prepared them, first, to find a husband and, second, for household activities. By 1834, there were nine private schools for girls, among them San Lázaro, de Ejercicios de Santa Rosa, del Espíritu Santo are few. The latter school was oriented to high-class girls, where they learned French, history, mythology, drawing, singing and dancing. During the guano boom the number of schools for girls increased. However, the range of subjects taught was practically the same. The Reglamento General de Instrucción of 1850 established the teaching of art, labours, languages and household activities for girls. In particular, the subjects for girls should be the following: drawing, music, sewing, unravelling, embroidery, weaving and other manual labours according to their gender, rules of urbanity, moral and domestic economics, Spanish grammar, arithmetic, French, English, descriptive geography, a brief notion of general history, rules of private hygiene and religion. Sciences were reserved for boys. Education prepared girls «for the household, not for the world of knowledge nor to learn a skill»(Zegarra 1998, p. 533).

The access of women to higher formal education increased over time. However, in the late $19^{\text {th }}$ century there were still large differences between men and women. Secondary education was primarily for men, whereas tertiary education was practically inaccessible for women. Women were accepted in universities only in 1908, although some women conducted studies independently (Villanueva 2010, p. 14).

In these circumstances, it is not surprising that women had a limited role in the economy. Married women were usually dedicated to household activities. Single women stayed at their parents' house or in the house of a relative. Widows stayed at home, usually living off the pension of their deceased husbands or from the rent of a house or a hacienda. Commercial directories show that women did not participate directly in the economy as professionals, merchants or artisans in Lima. Fuentes (1860), for example, indicated that among science and liberal arts professionals, women played a minor role. There were no female lawyers, doctors or musicians. Neither did women work as merchants, there being no female presence in the main merchant houses. Most artisans were also men. The participation of women in the labour market was mostly limited to a few services, in particular,

15 As Tschudi (1847) indicates, in the 1840s there were primary schools for boys and girls. Thirty-six primary schools were for boys and sixteen for girls. 
midwifery, laundry, sewing and cooking ${ }^{16}$. By 1876 the participation of women in the economy had not changed much ${ }^{17}$.

The fact that most women did not engage in commercial or productive activities outside their homes is also confirmed by our data of notarised contracts. A large number of contracts include information on the occupations of borrowers. Women were mostly featured as wives, widows or single, and in some cases as proprietors. For example, in 1860 there were twentyfour contracts with women as debtors. None of those contracts included a description of the occupation of the women. In contrast, men were typically described as merchants, agriculturists and proprietors. Other male borrowers were lawyers, doctors and state employees.

In summary, in $19^{\text {th }}$-century Peruvian society there was a clear prejudice against women. This prejudice may have had a direct impact on credit markets. If lenders prejudged women as less able to manage their finances, women would have been considered riskier borrowers than men; lenders would have then denied women access to credit, charged them higher interest rates or granted them smaller loans relative to their collateral. In addition, human capital may also have influenced the risk of default. Although there were no differences in the access of women and men to basic education, access to higher education was clearly a different case. If those differences in access to higher formal education influenced the ability to manage finances, then lenders may have rationally considered women, on average, less able to manage their finances and thus riskier borrowers than men.

Of course, prejudice and human capital may not have been the only factors that influenced lenders' perception of the risk of default. There might have been, for example, differences in property rights between women and men that could have influenced access to credit. If women had weaker property rights than men, they would have been riskier borrowers than men. Before analysing the possible impact of prejudice and differences in human capital on the allocation of credit, we will examine the financial legislation and, especially, the differences in property rights between women and men.

16 An important occupation among women was midwifery or partería. By 1860 , the main midwives in Lima were women; this was then an occupation exclusively limited to women. Laundry was also an important female activity. In total, in 1860 there were nine laundries and 3,147 washerwomen in the city. Women also worked as dressmakers in 1860. In total there were twentytwo of these establishments, employing 106 labourers or obreros; and 2,040 women dedicated to sewing in exchange for money. There were sixty-four picanterias (small, usually family-owned, restaurants) in Lima; three women owned three of the four main picanterías of the city. Other occupations included dyeing and the fabrication of candles.

17 In 1876, most women did not have an occupation outside their home. The Census of 1876 indicates that around 80 per cent of women did not have a profession or occupation outside their home. The percentage for men without a profession or occupation was 38 per cent. These differences in the percentage of men and women without an occupation cannot be explained by differences in the age distribution: the percentage of population of 15 years and older was practically the same for men and women. 


\section{LEGISLATION AND PROPERTY RIGHTS}

In the 1860 s and 1870 s mortgages were regulated by the civil code of 1851. According to this civil code, mortgage loans could be secured with real estate and other types of properties. The legislation was not especially restrictive. Individuals and companies could use a wide variety of properties to secure a loan. They could use real estate, merchandise, financial contracts and even their own salaries to secure loans.

The legislation was also not restrictive regarding the requirements to be a lender or borrower. Almost anyone could grant a mortgage loan or receive a loan as long as he or she was old enough and met some minimum requirements. Men and women, whether single or married, could lend and receive funds secured with a wide variety of properties.

The fact that almost any man or woman could engage in mortgage operations does not imply that men and women had exactly the same property rights. Some restrictions applied to the property rights of women that probably had an important effect on their participation in credit markets. In general, the civil legislation code established that men and women had the same rights and obligations. However, there were some exceptions, especially for married women ${ }^{18}$.

According to the civil code, the age of majority was $21^{19}$. At this age, individuals could inherit and manage property and their incomes and marry without parental consent. Women, like men, had the right to own properties. Single women, married women and widows could own houses, haciendas and other assets. This situation is confirmed by our sample.

According to the civil legislation, men and non-married women had similar rights over their properties and incomes. Like men, single women could sign contracts, sell properties and mortgage their estates. As indicated by García-Calderón (1879), non-married women were practically equal to men under the law ${ }^{20}$. In fact, between 1860 and 1875, a large number of single women and widows borrowed money secured by their estates without the authorisation of any other person. In total, around 20 per cent of contracts in our sample corresponded to non-married women who borrowed money without the authorisation of any other person.

By contrast, married women did not have the same rights as men. According to the civil code, married women were dependent on their husbands.

18 Only a few studies deal with women's property rights and the role of women in early credit market in Latin America, and most of those studies are focused on Mexico. One of the main studies of women's property rights in Latin America is that by Deere and León (2005). They show that in most of Latin America women had rights over their properties. However, when they got married, women lost partial control over their properties.

${ }_{19}$ Minors dependent on their parents, orphans depended on their guardadores and slaves on their masters.

${ }^{20}$ Although «with small differences» (García-Calderón 1879, vol. II, p. 1396). 
Marriage actually changed the situation of women. Married women did not lose their civil rights but these rights were seriously affected: in particular, married women could not exercise their rights without the approval of their husbands. For example, a married woman could not sell, mortgage or purchase estates without the intervention and approval of her husband.

In every marriage there were three types of properties: (a) properties that specifically belonged to the husband, (b) properties that belonged to the wife and (c) collective or common property, which belonged to both husband and wife $^{21}$. The individual property of the husband included what he obtained before marriage and any inheritances or donations acquired after marriage. The individual property of the wife consisted of the dowry, arras (the wedding gifts of the husband to the wife), paraphernalia (clothing, jewellery and household goods) and any inheritances or donations acquired after marriage. The common property of the couples consisted of any product (such as rent and interests) from the individual properties and the assets purchased from ordinary income from work or industry during the marriage.

The husband was the administrator of the three types of property, even of the wife's property, with the exception of the paraphernalia, which was managed by women ${ }^{22}$. Wives could mortgage their individual properties, but only with the authorisation of their husbands.

The fact that married women obtained loans with the authorisation of their husbands, however, may not necessarily have increased the risk for lending money to married women. It is true that married women did not have the same property rights as men. However, since husbands had to grant their authorisation for a loan, a loan to a married woman may have been perceived as a loan to her husband. Loans to married women may not necessarily have constituted highly risky loans.

The evidence shows, then, that loans to women were not associated with weaker property rights than loans to men, as unmarried women had the same property rights as men. In addition, loans to married women were the same as loans to their husbands. Property rights did not lead to differences in the risk of default between women and men.

\section{THE CREDIT MARKET OF LIMA}

Recent research shows that Peruvian credit markets experienced stagnation before the guano era ${ }^{23}$. Peru faced political instability and economic stagnation in the 1830s and early 1840s. Total exports, for example, remained

21 Several Latin American countries also had this division of properties (Deere and León 2005).

22 Also, married women could not be sued and could not sue personally, but through the intervention of their husbands.

${ }^{23}$ The figures on credit and interest rates in the first two paragraphs of this section come from Zegarra (2013a, 2013b). 
below six million soles in $1821-1847^{24}$. As a result, the supply of credit from private lenders was relatively stagnant and interest rates were high. Loans notarised by José de Selaya, for example, only increased from 19,000 soles per year in 1835-1840 to 22,000 soles per year in 1841-1845, whereas loans notarised by Ignacio and José Ayllón declined from 46,000 soles per year in $1835-1840$ to 22,000 soles per year in 1841-1845. Average annual interest rates in $1835-1845$ were high by international standards.

During the guano era the economic situation changed. From the late 1840 s, however, Peru became a politically more stable country and its export sector experienced important growth. Exports, for example, grew from 4.8 million soles in 1845 to 35 million in 1860. Exports then declined to 19 million soles in 1875, but levels were still much higher than in the 1850s. The level of credit then expanded and interest rates declined ${ }^{25}$. Loans notarised by José de Selaya, for example, increased from $<20,000$ soles in 1845 to $>220,000$ soles in 1855 and 455,000 soles in 1865, whereas loans notarised by Felipe Orellana increased from $<4,000$ soles in 1845 to almost 100,000 soles in 1855 and 245,000 soles in 1865 . In the late 1860 s and early 1870 s, mortgage credit continued increasing. Total mortgage credit secured by real estate in Lima, for example, increased by around 250 per cent between 1865 and 1873. Meanwhile, the average annual interest rate declined from $>20$ per cent in $1835-1845$ to $<14.6$ per cent in 1855 and 12.4 per cent in 1865 .

Credit markets in the 1860 s and early 1870 s mobilised many more resources than in the 1830 s and 1840 s. The market was apparently very competitive. In 1863, for example, our records include 74 private lenders for 97 loans; the largest lender accounted for only 7 per cent of total credit.

Mortgage credit markets, however, were still informal and largely local. Most lenders were individuals and sometimes companies; but not banks. The first commercial bank was created in 1862 and the first mortgage bank was chartered in 1866; even after the creation of banks, however, private lenders accounted for an important portion of the market. On the other hand, most lenders from Lima lent to borrowers from Lima. Interregional credit transactions hardly occurred between private lenders.

Loans by private lenders were secured by a wide variety of assets. Practically all loans indicated that the borrower would secure the loan with all present and future assets. In addition, most loans included a special mortgage, a more precise specification of the asset, which would guarantee the payment of the loan. These special mortgages consisted of real-estate properties, leasing contracts, capital goods, merchandise and even the borrower's salary. Other loans did not specify a special mortgage. These loans, also

\footnotetext{
24 Figures on exports come from Mitchell (1998).

25 Most Latin American economies experienced a significant expansion during this period as a result of the expansion of the world economy, partly due to the discovery of gold in California and the increase in the money supply (Marichal 1992).
} 
TABLE 1

PARTICIPATION OF MEN AND WOMEN BORROWERS IN THE CREDIT MARKET

\begin{tabular}{|l|r|r|r|r|}
\hline & \multicolumn{2}{|c|}{ Total credit } & \multicolumn{2}{c|}{ Number of loans } \\
\hline & (Soles) & $(\%)$ & (Number) & $(\%)$ \\
\hline Borrowers & & & & \\
Total & $4,920,980$ & 100 & 1,418 & 100 \\
Women & $1,057,547$ & 21 & 434 & 31 \\
$\quad$ Unmarried women & 201,761 & 4 & 96 & 7 \\
Widows & 423,885 & 9 & 179 & 13 \\
Married women & 404,033 & 8 & 142 & 10 \\
$\quad$ Unspecified & 27,869 & 1 & 17 & 1 \\
Men & $3,863,433$ & 79 & 984 & 69 \\
Lenders & & & & \\
Total & $4,920,980$ & 100 & 1,418 & 100 \\
Women & 883,210 & 18 & 344 & 24 \\
Men & $3,666,157$ & 75 & 1,018 & 72 \\
Companies & 371,614 & 8 & 56 & 4 \\
\hline
\end{tabular}

Note: The table only includes loans to individuals living in Lima and Callao.

Sources: Appendix A.

called general mortgages, may have been so ambiguous that they did not represent a binding obligation.

Most private lenders' loans were secured by urban real estate. In 1860-1875 around 59 per cent of all loans by private lenders were secured by urban estates, and only 8 per cent were secured by rural estates. In addition, 11 per cent of loans were secured by leasing contracts, capital goods and merchandise in urban and rural areas. Interestingly, 6 per cent of loans in 1860-1875 were secured by the debtors' wages. An important number of loans by private lenders (accounting for 12 per cent of the total number of loans) constituted general mortgages, that is, were only secured by all present and future goods of the debtors.

Much of the literature on $19^{\text {th }}$-century Peruvian credit markets has mentioned the role of men, especially merchants ${ }^{26}$. The role of women, however, remains unexplored. Did women participate in this booming credit market? The evidence suggests that they did. Widows, single women and wives participated in the credit markets both as lenders and as borrowers (Table 1). In the sample, female lenders accounted for 34 per cent of the total number of loans and 18 per cent of the total volume of credit; whereas female

${ }^{26}$ Camprubí (1957), for example, mentions that merchants played an important role offering credit. Merchants and commercial houses opened credit lines for their customers. 
TABLE 2

SIZE, INTEREST RATES AND MATURITY OF LOANS BY GENDER

\begin{tabular}{|l|c|c|c|}
\hline & $\begin{array}{c}\text { Average loan size } \\
\text { (soles) }\end{array}$ & $\begin{array}{c}\text { Average interest rate } \\
(\%)\end{array}$ & $\begin{array}{c}\text { Average maturity } \\
\text { (years) }\end{array}$ \\
\hline Total & $3,470.4$ & 15.4 & 1.62 \\
Women & $2,436.7$ & 16.5 & 1.74 \\
Unmarried women & $2,101.7$ & 18.0 & 1.95 \\
Widows & $2,368.1$ & 15.7 & 1.66 \\
Married women & $2,845.3$ & 16.4 & 1.73 \\
Men & $3,926.3$ & 14.9 & 1.56 \\
\hline
\end{tabular}

Note: The table only includes loans to individuals living in Lima and Callao.

Sources: Appendix A.

borrowers accounted for 31 per cent of the total number of loans and 21 per cent of the total volume of credit. Therefore, women participated in the credit market, but their participation was much lower than that of men.

In addition, women did not necessarily face the same loan conditions as men. The evidence, for example, indicates that women did not borrow the same amounts as men. The average loan size was 2,436 soles for female borrowers and 3,926 soles for male borrowers (Table 2). Therefore, men received not only a larger number of loans but also much larger loans. In addition, there were important differences in interest rates. On average the annual interest rates in 1860-1875 were 16.5 per cent for women and 14.9 per cent for men.

Why did women have a lower participation in the credit market? Why did women receive smaller loans and pay higher interest rates than men? Did gender discrimination influence the allocation of credit? The following two sections will be devoted to answering these questions.

\section{ACCESS TO CREDIT, LOAN SIZES AND THE DISTRIBUTION OF COLLATERAL}

This section discusses whether the differences in the participation in the credit market and in loan sizes between women and men resulted from gender discrimination or whether other relevant factors probably explained these differences. If women faced discrimination as a group, the probability that their loan applications were rejected would have been greater and the size of their loans smaller with respect to men, controlling for relevant individual characteristics.

Let us first address the question of whether women were discriminated against at the moment of application. Indeed, the legislation allowed husbands to restrict the participation of their wives in the credit market. If husbands had a prejudice against the participation of their wives in the credit market 
TABLE 3

PARTICIPATION OF WOMEN BORROWERS IN THE CREDIT MARKET, BY TYPE OF LOAN (SOLES)

\begin{tabular}{|l|c|c|c|c|c|c|}
\hline & \multicolumn{3}{|c|}{ Total credit } & \multicolumn{3}{c|}{ Number of loans } \\
\hline & Total & $\begin{array}{c}\text { Women } \\
\text { borrowers }\end{array}$ & $\begin{array}{c}\text { Men } \\
\text { borrowers }\end{array}$ & Total & $\begin{array}{c}\text { Women } \\
\text { borrowers }\end{array}$ & $\begin{array}{c}\text { Men } \\
\text { borrowers }\end{array}$ \\
\hline All loans & $4,920,980$ & $1,057,547$ & $3,863,433$ & 1,418 & 434 & 984 \\
Urban & $100 \%$ & $21 \%$ & $79 \%$ & $100 \%$ & $31 \%$ & $69 \%$ \\
estates & $2,592,926$ & 711,761 & $1,881,165$ & 843 & 348 & 495 \\
& $100 \%$ & $27 \%$ & $73 \%$ & $100 \%$ & $41 \%$ & $59 \%$ \\
Rural estates & 734,485 & 137,108 & 597,377 & 113 & 25 & 88 \\
& $100 \%$ & $19 \%$ & $81 \%$ & $100 \%$ & $22 \%$ & $78 \%$ \\
Urban chat- & 412,032 & 58,000 & 354,032 & 128 & 10 & 118 \\
tel & & & & & & \\
Rural chattel & 323,332 & 70,260 & 253,072 & 30 & 7 & 23 \\
& $100 \%$ & $22 \%$ & $78 \%$ & $100 \%$ & $23 \%$ & $77 \%$ \\
Wages & 85,420 & 4,382 & 81,039 & 84 & 4 & 80 \\
& $100 \%$ & $5 \%$ & $95 \%$ & $100 \%$ & $5 \%$ & $95 \%$ \\
\hline
\end{tabular}

Note: The table only includes loans to individuals living in Lima and Callao.

Sources: Appendix A.

as lenders or borrowers, they could simply not authorise them to do so. Prejudice could have had an effect on the participation of women in the credit market. However, gender discrimination would have operated through the family, not through the market ${ }^{27}$.

Furthermore, information on wealth and occupations suggests that the lower participation of female borrowers in the credit market was partly explained by the differences in collateral between women and men: women had lower proprietorship rates and a lower participation in the economy ${ }^{28}$.

Among loans secured by urban estates, for example, female borrowers accounted for 41 per cent of the total number of loans and 27 per cent of the total value of credit; whereas among loans secured by rural estates, female borrowers accounted for 22 per cent of the number of loans and 19 per cent of the value of credit (Table 3). The fact that the participation of women in mortgage loans was lower than that of men may be explained by the fact that

\footnotetext{
27 A similar case occurred in England during the Industrial Revolution (Burnette 2008).

28 Our data set does not include information on applications but only on loan contracts, so it is not possible to test the effect of gender on the probability of approval.
} 
women had a smaller participation in the distribution of collateral. We do not have information on the distribution of wealth in Lima in the 1860s and 1870s. However, information for 1839 shows that women owned fewer haciendas than men. In particular, out of 166 haciendas in the valleys of Lima, seventy-three were owned by men, fifty-four by women and thirty by companies ${ }^{29}$.

Among urban chattel mortgages, female borrowers accounted for only 8 per cent of the number of loans and 14 per cent of the value of credit. These loans were normally used by merchants and pulperos to fund their commercial operations. Most merchants and pulperos were men: in 1876 there were 2,919 merchants and pulperos, of which only seventy-one were women. Among rural chattel mortgages, female borrowers accounted for 23 per cent of the number of loans and 22 per cent of the value of credit. These differences are consistent with the structure of the population. In 1876, there were 4,501 agriculturists and rancheros in Lima, of which 3,579 were men and 922 women: only 20 per cent of agriculturists and rancheros were women.

Among loans secured by wages, women had a very small participation: female borrowers accounted for only 5 per cent of the number and value of such loans. These loans were secured by the wages of military personnel or state employees. Military personnel and state employees, however, were predominantly men: in 1876 there were 3,813 military personnel, all of them men; and 1,272 state employees, of which only sixty-five were women. It is difficult, then, to argue that loans secured by wages were discriminatory against women.

On the other hand, differences in loan sizes may also be largely explained by the distribution of wealth and collateral. If women had less valuable collateral than men and collateral influenced the size of loans, it would not be surprising that women received smaller loans than men. But were women less rich than men? We do not have information on the value of collateral, so we cannot prove with certainty that female borrowers in the sample were less rich than men. However, the hypothesis that women were less rich than men is supported by the fact that female lenders made smaller loans than male lenders. On average, female lenders made loans for 2,567 soles, whereas male lenders made loans for 3,759 soles (Table 4). This result suggests that female lenders had less money to lend than their male counterparts. Since women had limited options in the economy, they probably did not have the same capacity to accumulate wealth ${ }^{30}$.

29 There is no information about the ownership of nine haciendas.

30 On the other hand, the hypothesis that collateral influenced the size of loans is supported by the fact that within men there were important differences in the value of collateral and in the size of the loans. Consider the case of military personnel: some of these men probably did not have many assets and secured loans with their own salary. The figures from Table 4 indicate that the average figure for loans secured by wages was 1,016 soles, for loans secured by urban estates the figure was more than 3,000 soles and more than 6,000 soles in the case of loans secured by rural estates. These large differences are consistent with the fact that salaries were much lower than the value of collateral. 
TABLE 4

STATISTICS FOR SIZE

\begin{tabular}{|c|c|c|c|c|c|}
\hline Conditions & Mean & Standard deviation & Maximum & Minimum & Number of observations \\
\hline Conditions on gender variables & & & & & \\
\hline FEMALE $=1$ & 2,437 & 6,020 & 93,917 & 80 & 434 \\
\hline FEMALE $=0$ & 3,926 & 7,844 & 120,000 & 80 & 984 \\
\hline FEMALE-U = 1 & 2,275 & 3,917 & 44,800 & 100 & 275 \\
\hline FEMALE-U $=0$ & 3,789 & 8,001 & 120,000 & 80 & 1,126 \\
\hline FEMALE-M = 1 & 2,845 & 8,994 & 93,916 & 80 & 142 \\
\hline FEMALE-M $=0$ & 3,565 & 7,203 & 120,000 & 80 & 1,259 \\
\hline FEMALE-LENDER $=1$ & 2,567 & 5,177 & 80,000 & 160 & 344 \\
\hline FEMALE-LENDER $=0$ & 3,759 & 7,918 & 120,000 & 80 & 1,074 \\
\hline Conditions on MATURITY & & & & & \\
\hline MATURITY $\leqslant 1$ & 2,978 & 5,422 & 93,916 & 80 & 725 \\
\hline $1<$ MATURITY $\leqslant 2$ & 3,404 & 7,710 & 120,000 & 156 & 349 \\
\hline $2<$ MATURITY $\leqslant 5$ & 4,976 & 8,398 & 80,000 & 160 & 164 \\
\hline MATURITY $>5$ & 4,208 & 11,267 & 100,000 & 120 & 180 \\
\hline Conditions on the type of security & & & & & \\
\hline $\mathrm{URBAN}=1$ & 3,075 & 6,840 & 120,000 & 80 & 843 \\
\hline URBAN-R $=1$ & 3,219 & 4,516 & 32,000 & 160 & 128 \\
\hline RURAL $=1$ & 6,499 & 11,449 & 93,916 & 160 & 113 \\
\hline RURAL-R $=1$ & 10,777 & 19,889 & 80,000 & 218 & 30 \\
\hline $\mathrm{WAGE}=1$ & 1,016 & 1,288 & 10,400 & 120 & 84 \\
\hline GENERAL $=1$ & 3,705 & 5,117 & 28,800 & 240 & 159 \\
\hline OTHERS $=1$ & 3,009 & 4,304 & 24,000 & 80 & 61 \\
\hline
\end{tabular}


TABLE 4 (Cont.)

\begin{tabular}{|l|r|r|r|r|r|}
\hline Conditions on PERSONAL, REPUTATION and W & & & & \\
PERSONAL $=1$ & 4,963 & 8,877 & 54,120 & 80 & 43 \\
PERSONAL $=0$ & 3,423 & 7,310 & 120,000 & 80 & 1,375 \\
REPUTATION $=1$ & 2,559 & 3,216 & 16,000 & 240 & 60 \\
REPUTATION $=0$ & 3,510 & 7,492 & 120,000 & 80 & 1,358 \\
W 1 & 2,603 & 4,394 & 44,000 & 160 & 226 \\
W 0 & 3,801 & 7,922 & 100,000 & 80 & 837 \\
Conditions on other variables & & & & \\
INFLATION $\leqslant 0$ & 2,823 & 4,065 & 44,000 & 80 & 361 \\
INFLATION $>0$ & 3,691 & 8,181 & 120,000 & 80 & 1,057 \\
INTEREST-US $\leqslant 6$ & 3,009 & 3,434 & 20,000 & 80 & 287 \\
INTEREST-US $>6$ & 3,587 & 8,059 & 120,000 & 80 & 1,131 \\
GDP-GROWTH $\leqslant 0$ & 3,449 & 3,571 & 16,500 & 160 & 80 \\
GDP-GROWTH $>0$ & 3,471 & 7,531 & 120,000 & 80 & 1,338 \\
FT-GROWTH $\leqslant 0$ & 3,811 & 8,762 & 120,000 & 80 & 848 \\
FT-GROWTH $>0$ & 2,963 & 4,507 & 44,800 & 80 & 570 \\
D-1866 $=1$ & 3,764 & 6,876 & 51,368 & 80 & 94 \\
D-1866 $=0$ & 3,449 & 7,399 & 120,000 & 80 & 1,324 \\
D-1866-1875 $=1$ & 3,822 & 8,887 & 120,000 & 80 & 775 \\
D-1866-1875 $=0$ & 3,046 & 4,913 & 51,368 & 80 & 643 \\
\hline
\end{tabular}


Therefore, it seems that women had a lower participation than men in the total number of borrowers to a large extent because fewer women owned properties and because women had a limited participation in the economy. In addition, it seems that women received smaller loans because they were less rich than men.

Nevertheless, the fact that women had a lower access to credit and received smaller loans than men may be explained not only by differences in access to proprietorship or in the value of collateral. Other factors, including prejudice against women, may have influenced the participation of women and loan sizes. Since we do not have information on the value of collateral, however, our analysis in this section does not allow us to test whether other factors (including prejudice against women) influenced the participation of women in credit markets and loan sizes. Fortunately, we do have data for interest rates. The evidence for interest rates will allow us to test whether women were perceived as riskier borrowers than men and, in particular, whether gender discrimination played a role in the determination of interest rates.

\section{WHY DID WOMEN PAY HIGHER INTEREST RATES THAN MEN?}

One possible explanation for the differences in interest rates is that women were perceived as riskier borrowers than $\mathrm{men}^{31}$. If the property rights of women were weak, the ability of women to manage their finances was limited, and there was prejudice against women, lenders may have considered women to be riskier borrowers than men.

Property rights are crucial for evaluating the risk of default of a loan. Lending money to a person who has no clear property rights involves a higher risk than lending money to a person with clear property rights. In $19^{\text {th }}$-century Peru, however, property rights did not lead to differences in risk between men and women. Non-married men (including widowers) and non-married women (including widows) had the same property rights over their mortgaged properties. In addition, married women were dependent on their husbands' approval for mortgaging their properties. A loan to a married woman was probably considered similar to a loan to her husband, but secured by her properties; so loans to married women may have not suffered from a poor definition of property rights.

Limited access of women to education may have led lenders to perceive women as less able to manage their finances than $\mathrm{men}^{32}$. As explained in

${ }^{31}$ In theory, interest rates are largely influenced by the risk of default. Importantly, since usury laws were abolished in Peru in 1832, interest rates in the 1860s and 1870s may have reflected the risk of default. A law passed in Congress in December of 1832 established that all laws forbidding or restricting usury or interests on money were abolished. García-Calderón (1879) recognises that moneylenders could charge interest without any type of restriction.

${ }^{32}$ Blanchflower et al. (2003), for example, include education as a possible determinant for loan denial rates and interest rates. 
Section 1, basic education was similar for men and women: both genders had similar literacy rates. The main difference in human capital between women and men referred to the type of education and access to secondary and, especially, tertiary education. If these differences influenced the risk of default, then one must expect women to be charged higher interest rates.

Alternatively, prejudice against women may have influenced the lenders' perception of the ability of women to repay their loans. Some might argue that prejudice against women was probably higher in the past; and considering that early credit markets were largely informal and relied on personal linkages, prejudice may have had a large impact on credit allocation (Burnette 2008, p. 283). However, considering that there were a large number of lenders in the market of Lima in the 1860s and 1870s, prejudice may not have affected interest rates. After all, as several studies indicate, discrimination is less likely in very competitive markets (see e.g. Becker 1957; Cavaluzzo et al. 2002; Levine et al. 2008).

A multivariate analysis may allow us to determine the factors that influenced interest rates. Appendix A describes the data set and the variables included in the regressions. Table 5 reports some statistics for INTEREST and Table 6 reports the OLS results for INTEREST as dependent variable. Column 1 reports estimates from a regression that only includes the variable FEMALE as an explanatory variable. As expected, the coefficient of FEMALE is positive and highly significant. On average, according to this estimate, women paid 1.556 percentage points more than men. The $R^{2}$ coefficient, however, indicates that the variable FEMALE only explains 0.5 per cent of the variance of the dependent variable.

Since column 1 does not control for other relevant characteristics, the result for FEMALE cannot be interpreted as evidence that women were riskier borrowers than men. In fact, the coefficient of FEMALE may be biased owing to the fact that women received smaller loans than men and that, in the presence of fixed costs, small loans may have been more costly to provide than large loans. Women may, then, have been charged higher interest rates not because they were necessarily riskier, but simply because they were provided with smaller loans. In fact, interest rates were higher for smaller loans (Table 5). Thus, if women were perceived as riskier borrowers than men, the evidence must show that, controlling for the size of loans, interest rates charged to women were higher than those charged to men ${ }^{33}$.

Column 2 adds SIZE and MATURITY to the model. The variables SIZE and MATURITY are in natural logs. The effect of both variables is negative and statistically significant. In addition, the inclusion of SIZE and MATURITY increases the explanatory power of the model. The $R^{2}$ coefficient in column 2 is 0.089; so the variables SIZE and MATURITY explain around

33 Imperfect information may also lead to differences in interest rates depending on the value of the collateral. Bester (1985), for example, shows that lenders may find it optimal to give several loans with variable guarantees, where the interest rate depends negatively on the size of the guarantee. 
TABLE 5

STATISTICS FOR INTEREST

\begin{tabular}{|c|c|c|c|c|c|}
\hline Conditions & Mean & $\begin{array}{l}\text { Standard } \\
\text { deviation }\end{array}$ & Maximum & Minimum & $\begin{array}{c}\text { Number of } \\
\text { observations }\end{array}$ \\
\hline \multicolumn{6}{|c|}{ Conditions on gender variables } \\
\hline FEMALE $=1$ & 16.5 & 8.9 & 79.6 & 0.0 & \\
\hline FEMALE $=0$ & 14.9 & 10.8 & 213.8 & 0.0 & 871 \\
\hline FEMALE-U = 1 & 16.5 & 9.5 & 79.6 & 0.0 & 263 \\
\hline FEMALE-U $=0$ & 15.1 & 10.4 & 213.8 & 0.0 & 1,011 \\
\hline FEMALE-M = 1 & 16.5 & 8.0 & 51.1 & 0.0 & 140 \\
\hline FEMALE-M $=0$ & 15.3 & 10.5 & 213.8 & 0.0 & 1,134 \\
\hline \multicolumn{6}{|l|}{ Conditions on SIZE } \\
\hline SIZE $\leqslant 1,000$ & 18.6 & 14.2 & 213.8 & 0.0 & 478 \\
\hline $1,000<$ SIZE $\leqslant 2,000$ & 14.4 & 7.3 & 79.6 & 0.0 & 299 \\
\hline $2,000<$ SIZE $\leqslant 5,000$ & 13.6 & 5.2 & 42.6 & 0.0 & 294 \\
\hline $5,000<\mathrm{SIZE} \leqslant 10,000$ & 12.4 & 5.3 & 43.1 & 0.0 & 138 \\
\hline SIZE $>10,000$ & 11.7 & 4.4 & 26.8 & 0.0 & 81 \\
\hline \multicolumn{6}{|l|}{ Conditions on MATURITY } \\
\hline MATURITY $\leqslant 1$ & 16.6 & 12.2 & 213.8 & 0.0 & 687 \\
\hline $1<$ MATURITY $\leqslant 2$ & 14.6 & 6.1 & 42.6 & 0.0 & 334 \\
\hline $2<$ MATURITY $\leqslant 5$ & 13.4 & 7.2 & 60.1 & 0.0 & 160 \\
\hline MATURITY $>5$ & 13.2 & 9.3 & 79.6 & 0.0 & 109 \\
\hline \multicolumn{6}{|l|}{$\begin{array}{l}\text { Conditions on the type } \\
\text { of security }\end{array}$} \\
\hline $\mathrm{URBAN}=1$ & 16.3 & 10.7 & 213.8 & 0.0 & 817 \\
\hline URBAN-R = 1 & 13.7 & 7.7 & 60.1 & 0.0 & 121 \\
\hline RURAL $=1$ & 12.5 & 6.5 & 42.6 & 0.0 & 106 \\
\hline RURAL-R = 1 & 17.7 & 8.4 & 42.6 & 0.0 & 29 \\
\hline $\mathrm{WAGE}=1$ & 14.6 & 13.9 & 60.1 & 0.0 & 33 \\
\hline GENERAL $=1$ & 14.2 & 10.9 & 79.6 & 0.0 & 128 \\
\hline OTHERS $=1$ & 14.7 & 8.3 & 42.6 & 0.0 & 56 \\
\hline \multicolumn{6}{|c|}{$\begin{array}{l}\text { Conditions on PERSONAL, } \\
\text { REPUTATION and STATUS }\end{array}$} \\
\hline PERSONAL $=1$ & 13.6 & 9.3 & 42.6 & 6.0 & 30 \\
\hline PERSONAL $=0$ & 15.4 & 10.2 & 213.8 & 0.0 & 1,260 \\
\hline REPUTATION = 1 & 15.6 & 7.9 & 42.6 & 0.0 & 57 \\
\hline REPUTATION $=0$ & 15.4 & 10.3 & 213.8 & 0.0 & 1,233 \\
\hline $\mathrm{W}=1$ & 15.4 & 7.3 & 42.6 & 0.0 & 214 \\
\hline $\mathrm{W}=0$ & 15.6 & 11.5 & 213.8 & 0.0 & 771 \\
\hline
\end{tabular}


TABLE 5 (Cont.)

\begin{tabular}{|l|r|r|r|r|r|}
\hline Conditions on other variables & & & & & \\
INFLATION $\leqslant 0$ & 13.7 & 7.4 & 60.1 & 0.0 & 337 \\
INFLATION $>0$ & 16.0 & 11.0 & 213.8 & 0.0 & 953 \\
INTEREST-US $\leqslant 6$ & 14.6 & 8.3 & 60.1 & 0.0 & 272 \\
INTEREST-US $>6$ & 15.6 & 10.7 & 213.8 & 0.0 & 1,018 \\
GDP-GROWTH $\leqslant 0$ & 18.0 & 8.4 & 42.6 & 0.0 & 76 \\
GDP-GROWTH $>0$ & 15.2 & 10.3 & 213.8 & 0.0 & 1,214 \\
FT-GROWTH $\leqslant 0$ & 15.6 & 9.0 & 79.6 & 0.0 & 782 \\
FT-GROWTH $>0$ & 15.0 & 11.9 & 213.8 & 0.0 & 508 \\
D-1866 $=1$ & 18.0 & 10.1 & 60.1 & 0.0 & 87 \\
D-1866 $=0$ & 15.2 & 10.2 & 213.8 & 0.0 & 1,203 \\
D-1866-1875 $=1$ & 16.2 & 11.6 & 213.8 & 0.0 & 719 \\
D-1866-1875 $=0$ & 14.4 & 8.0 & 60.1 & 0.0 & 571 \\
\hline
\end{tabular}

8 per cent of the variance of the dependent variable. Importantly, the results indicate that when including these control variables, the effect of the variable FEMALE declines: the coefficient of this variable in column 2 is 0.7597 , a much smaller value than in column 1, and is not significant at a 5 per cent level.

Therefore, the fact that women paid higher interest rates than men does not necessarily imply that women were considered riskier borrowers than men. Since women received much smaller loans than men and smaller loans are associated with a higher unit cost for granting a loan, it is not surprising that women were charged higher interest rates. Controlling for the type of mortgaged property, economic conditions and year fixed effects, the coefficient of FEMALE declines and remains as non-significant at a 5 per cent level (columns 3-6).

The coefficient of FEMALE may capture the effect of relevant omitted variables that are correlated with gender, such as differences in education between women and men and prejudice against women. Therefore, the results in columns 2-6 suggest that, taken together, the differences in education between women and men and the prejudice against women do not seem to explain the differences in interest rates.

One potential problem with the OLS estimations in models 2-6 is that SIZE may be endogenous to INTEREST. In this case, the OLS estimates would be inconsistent. I then estimate the model in two stages, using FEMALE-LENDER as an instrument for SIZE. The first-stage results are reported in Table 7. Since FEMALE-LENDER has a significant effect on SIZE, and it is not endogenous to INTEREST, then the variable FEMALELENDER is a valid instrument for SIZE. Column 7 in Table 6 reports the 2SLS estimates. The coefficients of FEMALE and SIZE are different from 
TABLE 6

DEPENDENT VARIABLE: INTEREST

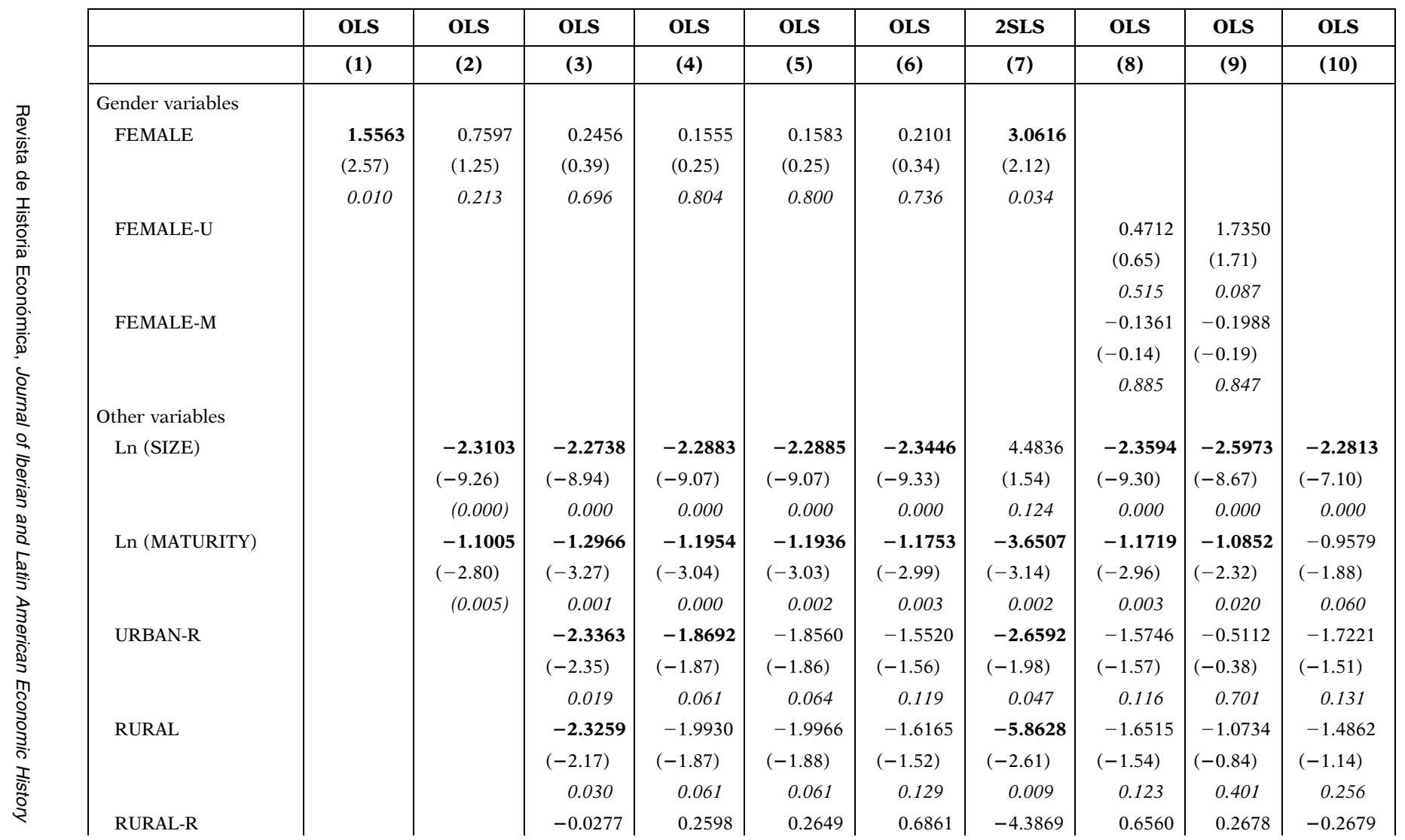


TABLE 6 (Cont.)

\begin{tabular}{|c|c|c|c|c|c|c|c|c|c|c|}
\hline & OLS & OLS & OLS & OLS & OLS & OLS & 2SLS & OLS & OLS & OLS \\
\hline & (1) & (2) & (3) & (4) & (5) & (6) & (7) & (8) & (9) & (10) \\
\hline GDP-GROWTH & & & & $\begin{array}{l}-0.1227 \\
(-1.57)\end{array}$ & $\begin{array}{l}-0.1228 \\
(-1.57)\end{array}$ & & & & & \\
\hline & & & & 0.118 & 0.118 & & & & & \\
\hline FT-GROWTH & & & & 0.0337 & 0.0335 & & & & & \\
\hline & & & & $(1.13)$ & $(1.12)$ & & & & & \\
\hline & & & & 0.258 & 0.263 & & & & & \\
\hline D-1866 & & & & 4.4985 & 4.4931 & & & & & \\
\hline & & & & $(2.73)$ & $(2.73)$ & & & & & \\
\hline & & & & 0.006 & 0.006 & & & & & \\
\hline D-1867-1875 & & & & 2.7328 & 2.7260 & & & & & \\
\hline & & & & $(2.93)$ & $(2.92)$ & & & & & \\
\hline & & & & 0.003 & 0.004 & & & & & \\
\hline EDUC & & & & & & & & & & -0.7975 \\
\hline & & & & & & & & & & $\begin{array}{r}(-0.49) \\
0.622\end{array}$ \\
\hline Year fixed effects & No & No & No & No & No & Yes & Yes & Yes & Yes & Yes \\
\hline$R^{2}$ & 0.0051 & 0.0898 & 0.0996 & 0.1232 & 0.1232 & 0.1410 & & 0.1419 & 0.1496 & 0.1391 \\
\hline Adjusted $R^{2}$ & 0.0043 & 0.0875 & 0.0928 & 0.1114 & 0.1107 & 0.1228 & & 0.1227 & 0.1240 & 0.114 \\
\hline $\begin{array}{l}F \text {-statistics/Wald-statis- } \\
\text { tics }^{1}\end{array}$ & 6.60 & 39.50 & 14.69 & 10.43 & 9.81 & 69.32 & 4.03 & 7.39 & 5.84 & 5.03 \\
\hline$P$-value ${ }^{1}$ & 0.010 & 0.000 & 0.000 & 0.000 & 0.000 & 0.000 & 0.000 & 0.000 & 0.000 & 0.000 \\
\hline $\begin{array}{c}\text { Number of observa- } \\
\text { tions }\end{array}$ & 1,290 & 1,205 & 1,205 & 1,205 & 1,205 & 1,205 & 1,205 & 1,189 & 924 & 804 \\
\hline
\end{tabular}

Notes: The table reports estimates for INTEREST as dependent variable. $T$-statistics are in parenthesis, $P$-values are in italics. Bold coefficients indicate that they are significant at a $5 \%$ level. Column 10 only includes loans to men. The Hausman statistics for model 7 is 11.94 and the $P$-value is 0.9587.

${ }^{1}$ The table reports $F$-statistics for OLS estimations and Wald tests for the 2SLS estimation. The $P$-value corresponds to the $F$-test or Wald test. 
TABLE 7

DEPENDENT VARIABLE: LN (SIZE)

\begin{tabular}{|c|c|}
\hline & (1) \\
\hline \multicolumn{2}{|l|}{ Gender variables } \\
\hline \multirow[t]{3}{*}{ FEMALE } & -0.3952 \\
\hline & $(-5.56)$ \\
\hline & 0.000 \\
\hline \multirow[t]{3}{*}{ FEMALE-LENDER } & -0.2825 \\
\hline & $(-3.76)$ \\
\hline & 0.000 \\
\hline \multicolumn{2}{|l|}{ Other variables } \\
\hline \multirow[t]{3}{*}{ Ln (MATURITY) } & 0.3777 \\
\hline & $(8.56)$ \\
\hline & 0.000 \\
\hline \multirow[t]{3}{*}{ URBAN-R } & 0.1287 \\
\hline & $(1.12)$ \\
\hline & 0.263 \\
\hline \multirow[t]{3}{*}{ RURAL } & 0.5916 \\
\hline & $(4.87)$ \\
\hline & 0.000 \\
\hline \multirow[t]{3}{*}{ RURAL-R } & 0.7194 \\
\hline & $(3.37)$ \\
\hline & 0.001 \\
\hline \multirow[t]{3}{*}{ WAGE } & -0.6484 \\
\hline & $(-2.89)$ \\
\hline & 0.004 \\
\hline \multirow[t]{3}{*}{ GENERAL } & 0.3798 \\
\hline & $(3.25)$ \\
\hline & 0.001 \\
\hline \multirow[t]{3}{*}{ OTHERS } & 0.1821 \\
\hline & $(1.12)$ \\
\hline & 0.263 \\
\hline \multirow[t]{3}{*}{ PERSONAL } & 0.1484 \\
\hline & $(0.70)$ \\
\hline & 0.483 \\
\hline$R^{2}$ & 0.1396 \\
\hline Adjusted $R^{2}$ & 0.1214 \\
\hline
\end{tabular}


TABLE 7 (Cont.)

\begin{tabular}{|l|c|}
\hline & (1) \\
\hline$F$-test, statistics & 7.65 \\
$F$-test, $P$-value & 0.000 \\
Number of observations & 1,205 \\
\hline
\end{tabular}

Notes: The table reports OLS estimates for $\ln (\mathrm{SIZE})$ as dependent variable. $T$-statistics are in the first parenthesis, $P$-values are in italics. Bold coefficients indicate that they are significant at a $5 \%$ level. Year fixed effects are included.

Loans included in the sample: FEMALE-M, FEMALE-S, FEMALE-W, MALE-S, MALE-W.

column 6. In particular, the coefficient of FEMALE in model 7 is much greater than in model 6. However, the Hausman statistic is 11.94 and the $P$-value is 0.9587 . At a 5 per cent level, I cannot reject the null hypothesis that OLS estimates in model 6 are consistent. Therefore, it seems that using SIZE as an explanatory variable does not generate an endogeneity problem. In addition, since OLS estimates are also efficient, our analysis must be based on OLS estimates, not on 2SLS estimates.

The civil status of female borrowers may have mattered for the perception of risk; so not controlling for civil status may yield biased coefficients. It is possible that non-married women were perceived as high risk borrowers. Since married women had to be authorised by their husbands to receive a loan, it is likely that married women obtained loans to invest in their husbands' occupations or businesses. In this case, a loan to a married woman was perhaps considered a loan to her husband and may then have been a loan with an associated low risk if the husband was educated and able to manage his finances properly. In contrast, loans to non-married women (including widows) were loans that they would use for their specific needs and that they would manage without male supervision. If women, probably not as educated as men, did not know how to manage their finances well, loans to women, in particular to non-married women, may have been riskier than loans to men.

Some might, however, tell a different story. In particular, it might be argued that loans to married women were riskier than loans to non-married women if such married women borrowers had husbands who were not able to accumulate capital. After all, a man who relied on his wife and, in particular, on his wife's assets to secure a loan, may not have accumulated wealth during his life to secure the loan. The fact that a married woman requested a loan may have been considered by lenders as a sign that her husband was not able to accumulate wealth, probably because of some inability to conduct businesses ${ }^{34}$.

${ }^{34}$ This is in fact Juliette Levy's hypothesis in her study of Yucatan's mortgage market (Levy 2012). Levy argues that married women in $19^{\text {th }}$-century Yucatan paid higher interest rates because their husbands were perceived, on average, as riskier borrowers than non-married women. 
To differentiate between non-married and married women, the model in column 8 includes the variables FEMALE-U and FEMALE-M. The coefficient of the variable FEMALE-U measures the difference in interest rates between non-married women (including widows) and men, whereas the coefficient of FEMALE-M measures the difference in interest rates between married women and men. The results indicate that the coefficient of FEMALE-U is positive and the coefficient of FEMALE-M is negative. If significant, these coefficients would be consistent with the hypothesis that unmarried women were perceived riskier than men owing to their lack of human capital and/or prejudice against them. However, both coefficients are not significant at a 5 per cent level. At a 5 per cent level, then, one cannot reject the hypothesis that women were charged the same interest rates as men, controlling for other factors. As indicated in column 9, controlling for the variable $\mathrm{W}$ does not change the main results ${ }^{35}$.

Some might find it surprising that gender did not influence interest rates, considering that women had lower human capital than men. If education influenced the ability of individuals to manage their finances, some might have expected interest rates to be influenced by gender. The results, however, may not be surprising if one considers that at the basic level there were no differences in education between women and men (literacy rates were the same for men and women) and that higher education did not seem to have an impact on risk of default. Column 10, for example, reports the results for a regression for male borrowers only. This model includes the variable EDUC, a dummy variable that adopts a value of 1 if the borrower was a lawyer or a medical doctor. The results indicate that this variable did not have a significant impact on INTEREST. Having access to tertiary education does not seem to have had an impact on the risk of default ${ }^{36}$.

Considering the fact that differences in education between women and men did not seem to have impacted interest rates, and the OLS coefficients of FEMALE in columns 2-6 and 8-10 are not significant, it seems that the evidence does not support the hypothesis that there was gender discrimination in credit markets during the guano era. Women may have experienced negative prejudice in several areas of Peruvian society but this prejudice does not seem to have played a key role in the determination of interest rates ${ }^{37}$.

35 The variable $\mathrm{W}$ may control for the effect of age and wealth and so it may have a negative effect on the dependent variable. W, however, is not a perfect proxy for age or wealth. In addition, in a considerable number of observations for which the borrower was a man, there is no information about the civil status of the borrower: the number of observations declines by 300 observations (almost 25 per cent of the sample) when including this variable. The results would have to be treated with care. Importantly, when controlling for this variable, the coefficients of FEMALE-U and FEMALE-M are still not significant at a 5 per cent level.

36 Similarly, Hunter and Walker (1996) find evidence of no significant impact of the applicant's education on the probability of approval of a loan for the U.S. mortgage market.

37 The evidence on the actual payment of loans is actually consistent with the fact that women were not riskier borrowers than men. Some loans include information on the actual date 


\section{CONCLUSIONS}

It is clear that women experienced much prejudice in the $19^{\text {th }}$ century. During the guano era, women were considered as having different goals in life as men and did not have the same access to higher education. Not surprisingly, women did not conduct the same jobs and businesses as men.

Prejudice against women could have affected the allocation of credit. If women were perceived as riskier borrowers than men, lenders would have been willing to grant only a few loans to women, would have granted women small loans relative to their collateral and would have charged them high interest rates.

The evidence indicates that women participated as borrowers and lenders in Peru during the guano era. However, there were important differences in access to credit and loan conditions between women and men. Among borrowers, women accounted for 31 per cent of the number of loans. In addition, loans to women were 38 per cent smaller than loans to men, and interest rates paid by women were 1.4 percentage points higher than those paid by men.

The evidence suggests that the differences in access to credit and loan conditions were partly explained by the distribution of wealth and collateral, and by the differences in the participation in the economy between women and men. Fewer women received loans probably owing to the fact that fewer women were estate owners and fewer women conducted business operations. In addition, women received smaller loans probably because their collateral had lower value.

The evidence for interest rates suggests that women were not riskier borrowers than men. There were important differences in interest rates between women and men but these differences resulted largely from differences in loan sizes. If women received small loans simply because they had low-value collateral, then in the presence of fixed costs for granting loans, it is not surprising that women were charged higher interest rates than men.

\section{REFERENCES}

Asiedu, E.; Freeman, J., and Nti-Addae, A. (2012): «Access to Credit by Small Businesses: How Relevant are Race, Ethnicity and Gender?». American Economic Review: Papers and Proceedings 102 (3), pp. 532-537.

\footnotetext{
(F'note continued)

of payment. It is then possible to calculate the time elapsed until the payment of the loan. A borrower who did not repay a loan on time can be considered riskier than a borrower who repaid his/her loan on time. The average time elapsed until the payment of the loan was 3.6 years for women and 3 years for men. For men and women, on average, loans were repaid long after the contractual date of payment. Considering the loans for which there is information on the maturity and on the actual date of payment, around 69 per cent of women borrowers did not repay their loans on time. Among men, the percentage of borrowers who did not repay their loans on time was 67 per cent. These default rates are very similar, which suggests that there were no differences in the risk of default between men and women.
} 
Avery, R.; Beeson, P., and Sniderman, M. (1996): «Accounting for Racial Differences in Housing Credit Markets», in J. Goering, and R. Wienk (eds), Mortgage Lending, Racial Discrimination, and Federal Policy. Washington, DC: Urban Institute Press, pp. 75-142.

Baydas, M.; MeYer, R., and Agullera-Alfred, N. (1994): «Discrimination Against Women in Formal Credit Markets: Reality or Rhetoric?». World Development 22 (7), pp. 1073-1082.

Becker, G. (1957): The Economics of Discrimination. Chicago: University of Chicago Press.

Bester, H. (1985): "Screening vs. Rationing in Credit Markets with Imperfect Information». The American Economic Review 75 (4), pp. 850-855.

Beveridge, A. (1985): «Local Lending Practice: Borrowers in a Small Northeastern Industrial City, 1832-1915». Journal of Economic History 45 (2), pp. 393-403.

Blanchflower, D.; Levine, P., and Zimmerman, D. (2003): «Discrimination in the SmallBusiness Credit Market». Review of Economics and Statistics 85 (4), pp. 930-943.

Blanchard, L.; Zhao, B., and Yinger, J. (2008): «Do Lenders Discriminate Against Minority and Woman Entrepreneurs?». Journal of Urban Economics 63 (2), pp. 467-497.

Bonilla, H. (1974): Guano y Burguesía en el Perú, Perú Problema 11. Lima: Instituto de Estudios Peruanos.

Burnette, J. (2008): Gender, Work and Wages in the Industrial Revolution. Cambridge, UK: Cambridge University Press.

Buvinic, M., and Berger, M. (1990): "Sex Differences in Access to a Small Enterprise Development Fund in Peru». World Development 18 (5), pp. 695-705.

Camprubí, C. (1957): Historia de los Bancos en el Perú: 1860-1879. Lima: Lumen.

Cavaluzzo, K., and Cavaluzzo, L. (1998): «Market Structure and Discrimination: The Case of Small Businesses». Journal of Money, Banking and Credit 30 (4), pp. 771-792.

Cavaluzzo, K.; Cavaluzzo, L., and Wolken, J. (2002): "Competition, Small Business Financing, and Discrimination: Evidence from a New Survey». The Journal of Business 75 (4), pp. 641-679.

Cosamalón, J. (1996): «Plebeyas Limeñas: Una Mirada al Trabajo Femenino», in S. O'Phelan, and M. Zegarra (eds), Mujeres, Familia y Sociedad en la Historia de América Latina. Siglos XVIII-XXI. Lima: CENDOC-Mujer, Pontificia Universidad Católica del Perú, Instituto Riva Agüero, Instituto Francés de Estudios Peruanos, pp. 263-286.

Deere, C., and León, M. (2005): «Liberalism and Married Women's Property Rights. Continuity and Change in Nineteenth Century Latin America». Hispanic American Historical Review 85 (4), pp. 627-678.

Dymski, G. (2006): «Discrimination in the Credit and Housing Markets: Findings and Challenges», in W. Rodgers (ed.), Handbook on the Economics of Discrimination. Cheltenham, UK: Edward Elgar, pp. 215-259.

Edelstein, D. (1977): Women and Credit Discrimination. Davis, CA: University of California at Davis.

Engelsen, J. (1978): «Social Aspects of Agricultural Expansion in Coastal Peru», PhD Dissertation in History. Los Angeles, CA: UCLA.

Fuentes, M. (1860): Guía Histórico-Descriptiva Administrativa, Judicial y de Domicilio de Lima. Lima: Librería Central.

García-Calderón, F. (1879): Diccionario de la Legislación Peruana, vols I and II. Lima: Francisco García-Calderón.

Gootenberg, P. (1990): "Carneros y Chuño: Price Levels in Nineteenth-Century Peru». Hispanic American Historical Review 70 (1), pp. 1-56.

HeLler, C., and HoudeK, J. (2004): «Women Lenders as Sources of Land Credit in NineteenthCentury Michigan». The Journal of Interdisciplinary History 35 (1), pp. 37-67. 
Hoffman, P.; Postel-Vinay, G., and Rosenthal, J. (1992): «Private Credit Markets in Paris, 1690-1840». The Journal of Economic History 52 (2), pp. 293-306.

HüNEFELD, C. (1988): Mujeres. Esclavitud, emociones y libertad. Lima 1800-1854. Lima: IEP.

Hunt, S. (1973): «Growth and Guano in Nineteenth Century Peru». Discussion Paper no. 34, Research Program in Economic Development. Princeton: Princeton University.

Hunter, W., and WaLker, M. (1996): «The Cultural Affinity Hypothesis and Mortgage Lending Decisions». Journal of Real Estate Finance and Economics 13 (1), pp. 57-70.

LÉvano, D. (2006): «Colegio, recogimiento o escuela. El Colegio de la Caridad. Un ejemplo de la educación femenina en Lima colonial», in M. Zegarra, and S. O'Phelan (eds), Mujeres, familia y sociedad en la historia de América Latina, siglos XVIII-XXI. Lima: CENDOC-Mujer, Pontificia Universidad Católica del Perú, Instituto Riva Agüero, Instituto Francés de Estudios Andinos.

LeVine, R.; LeVkov, A., and Rubinstein, Y. (2008): «Racial Discrimination and Competition», NBER Working Paper no. 14273.

Levy, J. (2012): The Making of a Market. Credit, Henequen and Notaries in Yucatan, 1850-1900. University Park, PA: The Pennsylvania State University Press.

Marichal, C. (1992): Historia de la Deuda Externa de América Latina. Madrid, Spain: Alianza América.

Mitchell, B. (1998): International Historical Statistics: The Americas 1750-1993. New York, N.Y.: Stockton Press.

Morrison, A.; Raju, D., and Sinha, N. (2007): Gender Equality, Poverty and Economic Growth. Washington, DC: World Bank.

Oliart, P. (1995): «Poniendo a cada quien en su lugar: Estereotipos raciales y sexuales en la Lima del siglo XIX», in A. Panfichi, and F. Portocarrero (eds), Mundos Interiores. Lima: Universidad del Pacífico, pp. 261-288.

Premo, B. (2006): «'El Modo de mi educación': Discursos sobre educación y los derechos de la madre en Lima, a finales del Virreynato", in M. Zegarra, and S. O'Phelan (eds), Mujeres, familia y sociedad en la historia de América Latina, siglos XVIII-XXI. Lima: CENDOC-Mujer, Pontificia Universidad Católica del Perú, Instituto Riva Agüero, Instituto Francés de Estudios Andinos, pp. 593-610.

Pressnall, L. S. (1956): Country Banking in the Industrial Revolution. Oxford: Clarendon Press.

QuinN, S. (2001): "The Glorious Revolution's Effect on English Private Finance: A Microhistory, 1680-1705». Journal of Economic History 61 (3), pp. 593-615.

Quiroz, A. (1993): Domestic and Foreign Finance in Modern Peru, 1850-1950. Financing Visions of Development. Pittsburgh, PA: University of Pittsburgh Press.

Quiroz, A. (1994): "Reassessing the Role of Credit in Late Colonial Peru: Censos, Escrituras, and Imposiciones». The Hispanic American Historical Review 74 (2), pp. 193-230.

Raturi, M., and Swamy, A. V. (1999): «Explaining Ethnic Differentials in Credit Market Outcomes in Zimbabwe». Economic Development and Cultural Change 47 (3), pp. 585-604.

Redish, A. (2003): «The Mortgage Market in Upper Canada: Window on a Pioneer Economy», in S. Engerman, P. Hoffman, J. Rosenthal, and K. Sokoloff (eds), Finance, Intermediaries, and Economic Development. Cambridge: Cambridge University Press, pp. 111-131.

Salinas, A. (2011): Las Damas del Guano. Género y modernidad en Lima, 1850-1879. Lima: Universidad Nacional Mayor de San Marcos. 
Schafer, R., and Ladd, H. (1980): Equal Opportunitiy: Accesibility to Mortgage Funds by Women and Minorities. Washington, DC: Department of Housing and Urban Development.

ShePARD, A. (2000): «Manhood, Credit and Patriarchy in Early Modern England c. 1580-1640». Past \& Present 167 (1), pp. 75-106.

Stiglitz, J., and Weiss, A. (1981): "Credit Rationing in Markets with Imperfect Information». The American Economic Review 71 (3), pp. 393-410.

Storey, D. J. (2004): «Racial and Gender Discrimination in the Micro Firms Credit Market? Evidence from Trinidad and Tobago». Small Business Economics 23 (5), pp. 401-422.

Suárez, M. (2001): Desafíos Transatlánticos: Mercaderes, Banqueros y el Estado en el Perú Virreynal, 1600-1700. Lima: Instituto Riva Agüero-PUCP.

Tschudi, J. J. (1847): Travels in Peru During the Years 1838-1842 on the Coast, in the Sierra, Across the Cordillera and the Andes, into the Primeval Forests. London: David Bogue.

Villanueva, V. (2010): El Poder en el Mundo Formal. Entre el voto y la cuota. Lima: Movimiento Manuela Ramos.

YINGER, J. (1996): «Discrimination in Mortgage Lending: A Literature Review», in J. Goering, and R. Wienk (eds), Mortgage Lending, Racial Discrimination, and Federal Policy. Washington, DC: Urban Institute Press, pp. 29-74.

Zegarra, L. F. (2013a): Institutions, Political Instability and Private Credit Markets in Lima. Lima: CENTRUM Católica (mimeo).

Zegarra, L. F. (2013b): Private Lenders, Mortgage Banks and Mortgage Credit in Peru. Lima: CENTRUM Católica (mimeo).

ZEgARRA, M. (1998): «Roles femeninos y perspectivas sociales en las décadas iniciales de la República. Una aproximación», in C. Meza, and T. Hampe (eds), La Mujer en la Historia del Perú (Siglo XV al XX). Lima: Fondo Editorial del Congreso del Perú, pp. 499-551.

\section{APPENDIX A}

\section{A.1 Data Appendix}

Notarial records constitute a rich source of information on mortgage credit markets in $19^{\text {th }}$-century Peru. The importance of notarial records for the study of mortgage credit market in Peru lies in the fact that the civil code of 1851 dictated that mortgages could only be constituted by registration with a notary (by escritura pública), indicating the main obligation and the goods that secured the loan ${ }^{38}$. Nowadays, notarial archives are kept in the National Archives of Peru (Archivo General del Perú).

Other types of loans were also granted in this period. Banks of issue and discount, for example, granted commercial loans. However, information on non-mortgage loans is highly limited. Our data set only refers to mortgage credit, where the security could be an estate, a leasing contract, merchandise, a salary or "all present and future goods», also known as general mortgages.

${ }^{38}$ In addition, mortgages had to be registered at the Office of Mortgages. 
This article relies on a sample of 1,646 new mortgage loans. I constructed this sample from notarial records, all of them taken from the National Archives of Peru. I selected the three notaries from the city of Lima with the longest series of notarial registration books (called protocolos) for 1860-1875: José de Selaya (1860-1875), Felipe Orellana (1860-1875) and Francisco Palacios (1862-1875). From the three notaries, I collected all contracts under the title of obligaciones, mutuos or hipotecas from January to May. From these contracts, I selected new mortgage loans granted by private lenders to borrowers living in the provinces of Lima and $\mathrm{Callao}^{39}$. I also restricted the sample to loans to individuals, excluding those to companies ${ }^{40}$.

The notaries of José de Selaya, Francisco Orellana and Francisco Palacios account for an important portion of the population of notarial contracts in the city of Lima. According to our calculations, for example, in the entire year of 1868, all notaries from Lima registered 247 loans by private lenders; the notaries of Selaya, Orellana and Palacios accounted for 57 per cent of the population. Similarly, for 1875, all notaries from Lima registered 505 loans by private lenders, and the three notaries accounted for 65 per cent of the population.

The contracts include information on the names of the lenders and debtors and the amount of the loan. In addition, most loans include the maturity of the loan, the interest rate and a description of the mortgaged property. Some contracts also include the actual date of payment.

\section{A.2 Multivariate Analysis. Data and Variables}

I employ a standard econometric methodology to test whether gender influenced interest rates ${ }^{41}$. Table A1 lists the variables included in the econometric models, and Table A2 reports a summary of statistics of the variables. The variable INTEREST measures the annual interest rate in percentage points.

The variables that may capture the effect of gender for borrowers are FEMALE, FEMALE-U and FEMALE-M. The variable SIZE measures the size

39 The archives contain data for loans to people from other provinces. However, including loans to individuals from other locations may bias the results. It is possible that lending to individuals from other cities was influenced by particular factors that cannot be measured at this point.

${ }^{40}$ Lending to companies may be influenced by important factors. Omitting those variables may yield biased results.

41 Mortgage loans by banks are not included in the econometric estimation for a simple reason: the legislation for mortgage banks was different from the legislation for private lenders. In fact, such legislation set a limit on interest rates and may then have reduced the variability of interest rates and loan conditions. In fact, all loans by mortgage banks charged exactly the same interest rate. The fact that the interest rate did not vary may be a result of the legislation rather than the fact that all borrowers were equally risky. In addition, variation in loan sizes among loans by mortgage banks may partly be the result of the legislation on mortgage banks. Therefore, including mortgage loans by banks in the sample may bias the results. Section 1 provides an explanation of the sample. 
TABLE A.1

LIST OF VARIABLES

\begin{tabular}{|c|c|}
\hline Variables & Description \\
\hline INTEREST & Annual interest rate in percentage points \\
\hline SIZE & Size of the loan in current silver soles \\
\hline FEMALE-U & $\begin{array}{l}\text { Dummy variable. It adopts a value of } 1 \text { if the borrower is an } \\
\text { unmarried woman or a widow, and } 0 \text { otherwise }\end{array}$ \\
\hline FEMALE-M & $\begin{array}{l}\text { Dummy variable. It adopts a value of } 1 \text { if the borrower is a } \\
\text { married woman and } 0 \text { otherwise }\end{array}$ \\
\hline FEMALE-LENDER & $\begin{array}{l}\text { Dummy variable. It adopts a value of } 1 \text { if the lender is a } \\
\text { woman }\end{array}$ \\
\hline MATURITY & Maturity of the loan in years \\
\hline PERSONAL & $\begin{array}{l}\text { Dummy variable. It adopts a value of } 1 \text { if the borrower and the } \\
\text { lender were relatives, and } 0 \text { otherwise }\end{array}$ \\
\hline REPUTATION & $\begin{array}{l}\text { Dummy variable. It adopts a value of } 1 \text { if the borrower had } \\
\text { received a loan from the same lender previously, and } 0 \\
\text { otherwise }\end{array}$ \\
\hline $\mathrm{W}$ & $\begin{array}{l}\text { Dummy variable. It adopts a value of } 1 \text { if the borrower is a } \\
\text { widow or a widower and } 0 \text { otherwise }\end{array}$ \\
\hline INFLATION & Inflation rate in percentage points lagged 1 year \\
\hline INTEREST-US & $\begin{array}{l}\text { Interest rate in the New York market in percentage points } \\
\text { lagged } 1 \text { year }\end{array}$ \\
\hline GDP-GROWTH & Growth rate of GDP in percentage points lagged 1 year \\
\hline FT-GROWTH & $\begin{array}{l}\text { Growth rate of the dollar value of foreign trade (exports plus } \\
\text { imports) in percentage points lagged } 1 \text { year }\end{array}$ \\
\hline D-1866 & $\begin{array}{l}\text { Dummy variable. It adopts a value of } 1 \text { for } 1866 \text { and } 0 \\
\text { otherwise }\end{array}$ \\
\hline D-1867-1875 & $\begin{array}{l}\text { Dummy variable. It adopts a value of } 1 \text { for } 1867-1875 \text { and } 0 \text { for } \\
1860-1866\end{array}$ \\
\hline URBAN & $\begin{array}{l}\text { Dummy variable. It adopts a value of } 1 \text { if the mortgaged } \\
\text { property is an urban estate and } 0 \text { otherwise }\end{array}$ \\
\hline URBAN-R & $\begin{array}{l}\text { Dummy variable. It adopts a value of } 1 \text { if the mortgaged } \\
\text { property is an urban non-estate property and } 0 \text { otherwise }\end{array}$ \\
\hline RURAL & $\begin{array}{l}\text { Dummy variable. It adopts a value of } 1 \text { if the mortgaged } \\
\text { property is a rural estate and } 0 \text { otherwise }\end{array}$ \\
\hline RURAL-R & $\begin{array}{l}\text { Dummy variable. It adopts a value of } 1 \text { if the mortgaged } \\
\text { property is a rural non-estate property and } 0 \text { otherwise }\end{array}$ \\
\hline WAGE & $\begin{array}{l}\text { Dummy variable. It adopts a value of } 1 \text { if the mortgaged asset } \\
\text { is the salary of the borrower and } 0 \text { otherwise }\end{array}$ \\
\hline GENERAL & $\begin{array}{l}\text { Dummy variable. It adopts a value of } 1 \text { if the contract is a } \\
\text { general mortgage or hipoteca general and } 0 \text { otherwise }\end{array}$ \\
\hline
\end{tabular}


TABLE A.1 (Cont.)

\begin{tabular}{|l|l|}
\hline Variables & Description \\
\hline OTHERS & $\begin{array}{l}\text { Dummy variable. It adopts a value of } 1 \text { if the type of security does } \\
\text { not belong to any of the previous categories and } 0 \text { otherwise. } \\
\text { Dummy variable. It adopts a value of } 1 \text { if the borrower is a } \\
\text { lawyer or a medical doctor and } 0 \text { otherwise }\end{array}$ \\
\hline
\end{tabular}

TABLE A.2

DESCRIPTIVE STATISTICS

\begin{tabular}{|c|c|c|c|c|c|}
\hline & Mean & $\begin{array}{l}\text { Standard } \\
\text { deviation }\end{array}$ & Maximum & Minimum & $\begin{array}{c}\text { Number of } \\
\text { observations }\end{array}$ \\
\hline INTEREST & 15.41 & 10.21 & 213.84 & 0.00 & 1,290 \\
\hline SIZE & $3,470.37$ & $7,363.94$ & $120,000.00$ & 80.00 & 1,418 \\
\hline FEMALE & 0.29 & 0.45 & 1.00 & 0.00 & 1,646 \\
\hline FEMALE-U & 0.19 & 0.39 & 1.00 & 0.00 & 1,628 \\
\hline FEMALE-M & 0.09 & 0.29 & 1.00 & 0.00 & 1,628 \\
\hline FEMALE-LENDER & 0.23 & 0.42 & 1.00 & 0.00 & 1,646 \\
\hline MATURITY & 1.63 & 1.43 & 11.46 & 0.04 & 1,270 \\
\hline URBAN & 0.59 & 0.49 & 1.00 & 0.00 & 1,449 \\
\hline URBAN-R & 0.09 & 0.29 & 1.00 & 0.00 & 1,449 \\
\hline RURAL & 0.08 & 0.27 & 1.00 & 0.00 & 1,449 \\
\hline RURAL-R & 0.02 & 0.15 & 1.00 & 0.00 & 1,449 \\
\hline WAGE & 0.06 & 0.23 & 1.00 & 0.00 & 1,449 \\
\hline GENERAL & 0.12 & 0.32 & 1.00 & 0.00 & 1,449 \\
\hline OTHERS & 0.04 & 0.21 & 1.00 & 0.00 & 1,449 \\
\hline PERSONAL & 0.03 & 0.17 & 1.00 & 0.00 & 1,646 \\
\hline REPUTATION & 0.04 & 0.20 & 1.00 & 0.00 & 1,646 \\
\hline $\mathrm{W}$ & 0.21 & 0.40 & 1.00 & 0.00 & 1,218 \\
\hline INFLATION & 3.86 & 8.47 & 28.91 & -9.31 & 1,646 \\
\hline INTEREST-US & 7.20 & 1.32 & 10.27 & 5.32 & 1,646 \\
\hline GDP-GROWTH & 2.01 & 3.97 & 15.81 & -5.17 & 1,646 \\
\hline FT-GROWTH & 3.43 & 17.98 & 53.64 & -11.01 & 1,646 \\
\hline D-1866 & 0.07 & 0.25 & 1.00 & 0.00 & 1,646 \\
\hline D-1867-1875 & 0.55 & 0.50 & 1.00 & 0.00 & 1,646 \\
\hline EDUC & 0.03 & 0.17 & 1.00 & 0.00 & 1,646 \\
\hline
\end{tabular}


of the loan in silver soles ${ }^{42}$. MATURITY allows us to control for the maturity of the loan. The variables URBAN, URBAN-R, RURAL, RURAL-R, WAGE, GENERAL, OTHERS allow us to control for the type of mortgaged property. The variable PERSONAL measures whether the borrower and the lender were relatives, and the variable REPUTATION measures whether the borrower had borrowed from the same lender previously. Lenders probably charged less to their relatives; in addition, lenders probably considered individuals they had granted loans to previously to be less risky. On the other hand, the variable $\mathrm{W}$ may allow us to control for age and wealth ${ }^{43}$. It is possible that widows and widowers were older and richer than married people. If older and richer individuals were less risky, W may have had a negative effect on interest rates ${ }^{44}$.

On the other hand, INFLATION and INTEREST-US may have had a negative effect on the supply curve of credit. Meanwhile, the effect of GDPGROWTH and FT-GROWTH on interest rates is ambiguous: the growth of domestic production and foreign trade may have had a positive impact on the supply of funds and the demand for credit ${ }^{45}$. The dummy variable D-1866 may capture the effect of the war against Spain in 1866 and may thus have had a positive effect on the risk of default. The dummy variable D-1867-1875 may capture the effect of the creation of mortgage banks. It is possible that as mortgage banks were created from the end of 1866 private lenders ended up with riskier borrowers.

42 FEMALE-LENDER may capture the effect of gender for lenders. If women were less rich than men, female lenders probably made smaller loans than male lenders.

43 Since this variable is far from a perfect proxy for age and wealth, the econometric results when including this variable must be treated with care.

44 The evidence suggests that widowed men and women were older than single and married individuals. Using data from the Census of Peru of 1876 for the districts of the province of Lima, for example, I find that a correlation of 0.63 between the percentage of widows and widowers and the percentage of people older than 50 years, and a correlation of 0.65 between the percentage of widows and widowers and the percentage of people older than 60 years.

45 Since the effect of the variables INFLATION, INTEREST-US, GDP-GROWTH and FT-GROWTH may not be immediate, they are lagged 1 year. 